\title{
Contribution to improvement of the traditional extraction of olive oil by pressure from whole and stoned olives by addition of a co-adjuvant (talc)
}

\author{
Khayreddine Titouh ${ }^{1, *}$, Azzedine Mazari ${ }^{1}$ and Mohand Zine Aït Meziane ${ }^{2}$ \\ ${ }^{1}$ National Institute of Agronomic Research of Algeria (INRAA), Centre of Baraki, Algiers, Algeria \\ ${ }^{2}$ National Institute of Agronomic Research of Algeria (INRAA), Oued Ghir Station, Béjaïa, Algeria
}

Received 26 November 2019 - Accepted 18 March 2020

\begin{abstract}
The olive growing is one of the strategic sectors of the Algerian economy. Traditional olive culture located in the mountains of Kabylia offers typical oil widely preferred by a large part of the Algerian consumers. However, this ancestral culture risks not only abandonment but suffers much more from uncontrolled of the good practices surrounding this local product requiring a valorization accompanied by improvement. Indeed, the difficulty to extract the total oil contained in the fruit is one of the main obstacles of the extraction method particularly by pressure. Nevertheless, some actions as the addition of co-adjuvant during the malaxing process allow improving efficiency of the extraction process. Our results indicate that the addition of $2.5 \%$ of talc as a co-adjuvant to a moistless paste obtained from whole olives significantly improves the oil yield by about $4.4 \%$ without altering the acidity compared to the control. Similarly, stoning improves the moisture of the pressed mass although without improving yield of the oil characterized by a slight decrease in acidity compared to other extracted oils. Therefore, our results confirm the beneficial effect of talc on the extraction of olive oil and contribute to the improvement of the traditional extraction by pressure to enhance the value of this local product.
\end{abstract}

Keywords: co-adjuvant / extraction / olive oil / pressure / stoning

\begin{abstract}
Résumé - Amélioration de l'extraction traditionnelle de l'huile d'olive par pression à partir d'olives entières et dénoyautées par l'ajout d'un co-adjuvant (talc). L'oléiculture est l'un des secteurs stratégiques de l'économie algérienne. La culture traditionnelle de l'olivier dans les montagnes de Kabylie offre une huile typique largement préférée par une grande partie des consommateurs algériens. Cependant, cette culture ancestrale risque non seulement d'être abandonnée mais souffre davantage encore de la non-maîtrise des bonnes pratiques entourant ce produit local nécessitant une valorisation accompagnée d'une amélioration. En effet, la difficulté d'extraire la totalité de l'huile contenue dans le fruit est l'un des principaux obstacles de la méthode d'extraction notamment par pression. Néanmoins, certaines actions comme l'ajout de co-adjuvant lors du malaxage permettent d'améliorer l'efficacité du processus d'extraction. Nos résultats indiquent que l'ajout de $2,5 \%$ de talc comme co-adjuvant à une pâte moins humide obtenue à partir d'olives entières améliore significativement le rendement en huile d'environ $4,4 \%$ sans altérer l'acidité par rapport au témoin. De même, le dénoyautage améliore l'humidité de la masse pressée sans toutefois améliorer le rendement de l'huile caractérisée par une légère diminution de l'acidité par rapport aux autres huiles extraites. Par conséquent, nos résultats confirment l'effet bénéfique du talc sur l'extraction de l'huile d'olive et contribuent à l'amélioration de l'extraction traditionnelle par pression pour valoriser ce produit local.
\end{abstract}

Mots clés : co-adjuvant / extraction / huile d'olive / pression / dénoyautage

\footnotetext{
*Correspondence: titouhkheireddine@gmail.com
} 


\section{Introduction}

The olive tree (Olea europaea L. ssp. europaea) is one of the species characterizing the Mediterranean basin. A diploid species belonging to the Oleaceae family, the olive tree includes wild (var sylvestris) and cultivated varieties (var sativa) for their fruit in order to extract the oil or consumed, after processing, as table olives (Rugini and Baldoni, 2005). Over an area of 12 million hectares and an average annual production of 20 million tons of olives of which $90 \%$ are to produce about 3 million tons of oil, olive is one of the world's major oilseed crops after soybean, rapeseed, sunflower and oil palm (FAOSTAT, 2017; IOC, 2018).

In Algeria, olive growing occupies more than $40 \%$ of the areas dedicated to fruit crops. With an orchard of 57 million olive trees planted over approximately 470 thousand hectares, Algeria produces nearly 700 thousand tons of olives of which $60 \%$ is for the extraction of oil (MARDF, 2017). Algeria produce about 77 thousand tons of olive oil equivalent to $4 \%$ of the world production, ranking so the 9th after Portugal and Turkey (IOC, 2018). Indeed, more than $50 \%$ of the national production of olives for oil extraction comes mainly from three department of "Kabylia": Béjaïa, Tizi Ouzou and Bouira (MARDF, 2017) accounting more than $44 \%$ of the national olive area (Aït Mouloud, 2014). Furthermore, at least $65 \%$ of oil mills are located in that region where more than $60 \%$ are of traditional type (Lamani, 2014).

Olive oil technology and good farming practices are a key element to obtain a high quality olive oil in important quantities (Alba, 2008). In Algeria, olive growing has been maintained for a long time in the form of a familiar crop, particularly in the mountainous regions (Lamani and Ilbert, 2016a), where the oil extraction is mainly carried out in a traditional manner within oil mills operating with the mechanical or hydraulic press system while the continuous system represents less than $20 \%$ of the olive oil chain (Mendil, 2009). Indeed, the uncontrolled process of extraction by pressure often causes a considerable oil loss of about 5 to $8 \%$ with a deterioration of the quality of the product obtained compared to the modern system (López-Villalta et al., 2008).

A large part of the Algerian consumers choose olive oil from their region of origin and buy it directly from the mill during the harvest season (Lamani and Ilbert, 2016a, b). In fact, compared to stone mills used in traditional oil mills; metal crushers in modern chains lead to pungent, bitter, greenish oils following a significant release of polyphenols from fruits and shredded leaves, particularly in cultivars producing naturally this kind of oil (Di Giovacchino et al., 2002b; Preziuso et al., 2010). In addition, consumer demand for organic olive oils has greatly increased in recent years due to their superior taste and high nutritional quality in relation to production conditions considering the surrounding environment (García-González et al., 2014). As a result, so-called "traditional" oils such as "Kabylie" olive oil benefit from collective recognition inside and outside the region and respond to Algerian consumer appreciations by its specific organoleptic characteristics (typical taste, acute smell and a clear color) despite not being adapted to international standards (Hadjou et al., 2013; Ait Mouloud, 2014; Lamani, 2014; Bouyoucef and Laoudj, 2016; Lamani and Ilbert, 2016a). Nevertheless, in recent years, Algerian olive growing considered as strategic sector has undergone profound changes, for its upgrading (mechanization, new plantations, fertilization and irrigation, etc.) necessary for its integration into the world economy (Boudi et al., 2013; Ait Mouloud, 2014). In this context, the olive processing sector has experienced a real development by the creation and modernization of oil mills (Hadjou et al., 2013) with a gradual neglect of the traditional type. Consequently, this ancestral technique considered as a socio-cultural heritage as well as the extracted olive oil, an excellent local product, tend to be neglected. However, a few accompanying measures such as the attribution of geographical indication labels for local products, organizations of olive festivals and diffusion programs of good practices as well as rehabilitation of the traditional mills (Mendil, 2009; Hadjou et al., 2013; Aït Mouloud, 2014; Lamani, 2014) in addition to the historic relation of this method of extraction with local traditions (Lamani and Ilbert, 2016a) have contributed significantly to the maintenance and preservation of this technique and derived product.

The yield and extractability of olive oil vary according to the degree of maturity of the olive, conditions of cultivation, efficiency of the extraction equipment but much more to the cultivar (Beltrán et al., 2003; Vidal et al., 2018). So, maximizing the yield of good quality oil is the main objective of the olive industry (Caponio et al., 2016). Indeed, the total oil of which more than $90 \%$ is located in the pulp can't be extracted because there are always losses in the generated byproducts especially in cultivars producing pastes calcified as "difficult" to elaborate (Beltrán et al., 2003). However, despite the type of extraction, some practices can improve the oil extractability without affecting its quality. Prior preparation of the paste is a fundamental factor for better extraction of the oil particularly by pressure (Di Giovacchino et al., 2002b; Alba, 2008). Among the preparation methods, malaxing under slow rotation (20-30 rpm) allows the lipid droplets aggregation and their separation as free oil (Clodoveo, 2012). Nevertheless, rapid and longer malaxation particularly under high temperature affects negatively the yield as well as the quality characteristics of the product (Di Giovacchino et al., 2002a, b; Stefanoudaki et al., 2011; Clodoveo, 2012; Guermazi et al., 2015; Caponio et al., 2016). According to Fernández Valdivia et al. (2008), the addition of water can be effective when the humidity of the olives is too low, although its addition to a normal paste decreases not only the oil yield and its extractability but also causes the deterioration of its quality (Carrapiso et al., 2013). Nevertheless, some products called "technological co-adjuvant" such as enzymes, common salt, calcium carbonates or talc (hydrated magnesium silicates) are able to disintegrate the reticular matrix during malaxation, reduce the emulsion and thus facilitating the separation of the oil. The co-adjuvant improves the texture of the mass which increases the yield without affecting the composition or the characteristics of the extracted oil (Fernández Valdivia et al., 2008; López-Villalta et al., 2008; Clodoveo, 2012; Carrapiso et al., 2013; Caponio et al., 2016). According to Caponio et al. (2016), talc is often added at concentrations up to $5 \%$ depending on the moisture of the fruit and the duration of mixing. However, an overdose of talc can reduce the efficiency of the process (Clodoveo, 2012). Uceda et al. (2008) confirm that oils extracted following the addition of co-adjuvants do not exhibit any physico-chemical or organoleptic alterations. 
In addition, the obtained oil is free of talc which is released into the pomace due to its high specific weight $\left(2.8 \mathrm{~g} / \mathrm{cm}^{3}\right)$ (Di Giovacchino et al., 2002b).

Stoning of olives has been proposed as an alternative for crushing the whole fruits during the oil extraction process (Patumi et al., 2003). According to Guermazi et al. (2015) the absence of the stones allows to preserve the humidity of the paste thus avoiding the addition of water during the malaxation. In addition, the stoning improves the physicochemical and sensory quality of the extracted oil compared to that obtained from whole olives (Luaces et al., 2004; Ranalli et al., 2009). As a result, this type of oil rich in volatile compounds is more stable and resistant to auto-oxidation due to its high content of phenolic compounds (Guermazi et al., 2015) as well as the weak activation of enzymes involved in oxidation of fatty acids (Ranalli and Contento, 2010) whose inactivity is associated with the absence of the stone, rich in lipoxygenases, during malaxation (Patumi et al., 2003). In addition, the kernel is exploited in the pharmaceutical industry while stones can be used in construction or as source of energy (Ranalli et al., 2009). Therefore, this kind of oil, often produced in organic or biological agriculture, is reaching importance in recent years for its high organoleptic quality and its added value can contribute significantly in the development of so-called "traditional" oils.

Therefore, our study is a contribution to enhance the olive oil traditionally produced by pressure via the evaluation of the effect of stoning of olives as well as addition of a co-adjuvant often used in modern oil mill (talc) during malaxation of the paste on the yield of extracted oil.

\section{Material and methods}

\subsection{Plant material}

The well developed and matures (all black) olives of the cultivar "Tabelout" were recovered from the middle part of the tree, particularly the south facing one. The maturity index was determined on a sample of 100 fruits according to the method proposed by Uceda and Frías (1975). Olive trees aged 10 years old are sampled from the olive collection of the National Institute of Agronomic Research of Algeria (INRAA) at experimental station of Oued Ghir-Béjaïa (Hamdi and Khanouche, 2007). The average weight of extracted fruits and stones was obtained using a precision scales while the length and width of the samples were performed with a caliper. Subsequently, the ratio "pulp/fruit" and "pulp/stone" indicating the proportion of the pulp with respect to all the fruit or stone in addition to pulp thickness are calculated by the following formulas:

$$
\begin{aligned}
\text { Pulp } / \text { Fruit ratio }(\%) & =\frac{(\text { Fruit weight }- \text { Stone weight })}{\text { Fruit weight }} \\
& \times 100,
\end{aligned}
$$

Pulp/Stone ratio $(\mathrm{w} / \mathrm{w})=\frac{(\text { Fruit weight }- \text { Stone weight })}{\text { Stone weight }}$,
Pulp thickness $(\mathrm{cm})=\frac{(\text { Fruit diameter }- \text { Stone diameter })}{2}$.

\subsection{Olive oil extraction and determination of the free acidity}

The fruits were washed under running water. Crushing of whole or stoned olives is done with a metal crusher. Stoning is carried out with a manual stoner machine in order to recover the maximum of the pulp. The paste obtained after crushing was malaxated for $30 \mathrm{~min}$ at slow rotation $(20 \mathrm{rpm})$ with heating in a water bath at a temperature less than $30^{\circ} \mathrm{C}$ in addition or not of $2.5 \%$ of talc (hydrated magnesium silicates $\left.\mathrm{Mg}_{3} \mathrm{Si}_{4} \mathrm{O}_{10}(\mathrm{OH})_{2}\right)$ as co-adjuvant spread on the surface of the weighed paste. The moisture content was determined by drying $10 \mathrm{~g}$ of malaxated paste before pressing $(h)$ and in the case of pomace after extraction $\left(h^{\prime}\right)$ at $105^{\circ} \mathrm{C}$ until obtaining a constant weight. The rates are calculated as follows:

$$
\text { Moisture content }(\%)=\frac{\left(w_{i}-w_{f}\right)}{w_{i}} \times 100,
$$

where: $w_{i}$ : initial weight of the paste $(10 \mathrm{~g}) ; w_{f}$ : final weight of the paste after drying at $105^{\circ} \mathrm{C}$.

In order to reproduce the conditions of traditional extraction by pressure, the malaxated paste was pressed with a mechanical press for $30 \mathrm{~min}$ with a decrease in pressure $5 \mathrm{~min}$ before the end followed by a new pressure to extract the maximum of the liquid containing the oil. This liquid was kept in separator funnel allowing sedimentation of solid impurities and water to recover the oil on the surface. The extracted oil was centrifuged at $3000 \mathrm{rpm}$ for 10 to $15 \mathrm{~min}$ to purify the product. The volume of recovered oil was determined $\left(v_{o}\right)$ in a graduated burette to estimate oil yield in humid $\left(O_{h}\right)$ as follows:

$$
O_{h}(\%)=\frac{\left(v_{o} \times 0.915\right)}{w_{i}} \times 100
$$

where: $v_{o}$ : volume of the extracted oil; $w_{i}$ : initial weight of the paste $(200 \mathrm{~g}) ; 0.915$ : density of the oil.

Subsequently, oil yield in dry $\left(O_{d}\right)$ is calculated as follows:

$$
O_{d}(\%)=\frac{\left(O_{h}\right)}{100-h} \times 100
$$

The degree of acidity of the purified oil expressed as a percentage of free oleic acid was determined according to the European official method of oil regulation (EEC) $\mathrm{N}^{\circ} 2568 / 91$ (EEC, 1991) by titration with $\mathrm{KOH}$ at $0.1 \mathrm{~N}$ of $10 \mathrm{~g}$ of oil mixed with a previously neutralized solvent of alcohol-ether $(1: 1)$ in presence of phenolphthalein as indicator.

\subsection{Statistical analysis of the data}

The different results obtained from the various tests were subjected to an analysis of variance (ANOVA) followed by a multiple comparison with the LSD test at a significance level 
Table 1. Biometric characteristics of olives and stones of the cultivar "Tabelout".

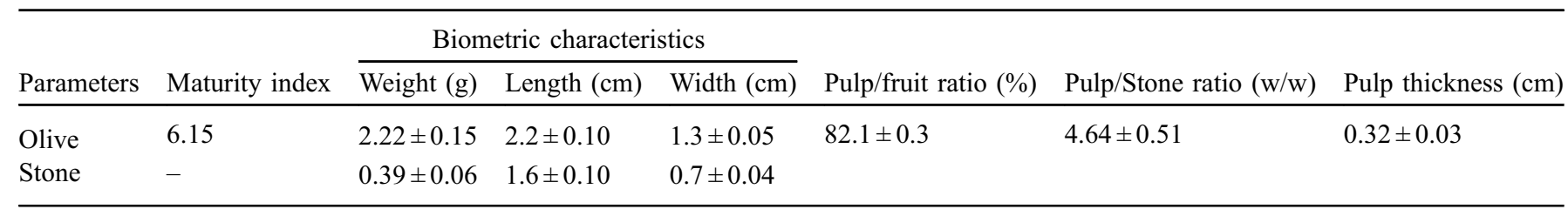

of $5 \%$. Values followed by the same letters are not significantly different. The software used for all analyzes is XLStat (Version 2016.02.27444).

\section{Results and discussion}

The biometric characteristics of the olives and stones of the cultivar "Tabelout" used in the study are summarized in Table 1. The fruits are elongated and have a medium weight with a moderately thick pulp, representing more than $82 \%$ of the total weight of the fruit while the core does not exceed $18 \%$ of the weight of the olive (Fig. 1).

The obtained results indicate that the crushing of mature olives with a high maturity index of 6.15 (Tab. 1) results in a paste containing less than $43 \%$ of moisture (Tab. 2). According to Beltrán et al. (2008) and Espínola Lozano et al. (2009), the moisture content of fruits decreases proportionally with their degree of ripening. In fact, stoned olives contain more water $(49 \%)$ than whole fruits $(43 \%)$ (Tab. 2). This difference in humidity is due that at full maturity more than $90 \%$ of the water contained in the olive is located in the pulp which can contain up to $60 \%$ of moisture (Beltrán et al., 2008; López-Villalta et al., 2008).

The stoning causes a slight decrease of about 1.1 percent point of the oil yield compared to the extraction from whole fruits giving $16.2 \%$ of oil (Tab. 2). According to Beltrán et al. (2003, 2008) and López-Villalta et al. (2008) at least $97 \%$ of the oil contained in the olive, depending to the cultivar, is located in the pulp (52\% of its dry weight) while the stone including kernel contains less than $3 \%$ of the total oil representing around $0.8 \%$ of its total dry weight. Stoning results in moisture-rich pastes avoiding the addition of water during the extraction process (Guermazi et al., 2015). However, high moisture content results in difficult paste and increases the emulsion resulting in low amounts of extracted oil (Sadkaoui et al., 2017; Vidal et al., 2018) as in our case (Fig. 1). Our results confirm observations of Ranalli et al. (2009) indicating that low oil yields are obtained from stoned olives. In fact, the angular and sharp parts resulting from the crushing of the stones contribute to break the uncrushed oleic cells during malaxation of the paste. As a result, the absence of these parts leads to a decrease around $3 \%$ in oil production, especially in fruits at the beginning of maturity which contain high water content (Patumi et al., 2003). In our case, the slight decrease in oil yield can be explained by the advanced maturity of the olives, usually characterized by a reduction in the moisture content. Therefore, the extraction of oil from stoned fruits can't be mechanically completed (Patumi et al., 2003) which requires the use of additives to improve the extractability (Ranalli et al., 2009). These authors noted a significant improvement in oil yield accompanied by a

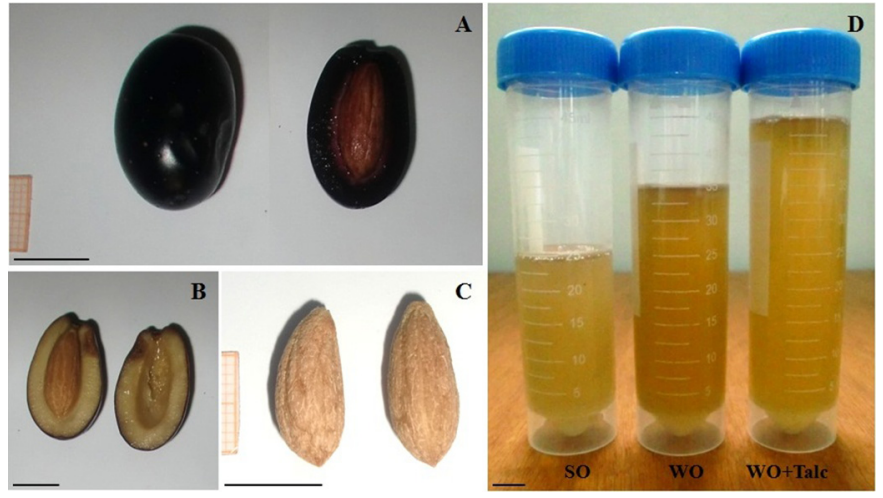

Fig. 1. Olives used (A and B), stones (C), aspect and volume of the oil extracted (D) from stoned (SO) or whole olives (WO) of the cultivar "Tabelout" in absence or presence of talc as co-adjuvant during malaxation (bars correspond to $1 \mathrm{~cm}$ in reality).

reduction in lipid losses in the by-products generated when adding talc at $2 \%$ to the paste from stoned olives. In our case, the addition of talc at $2.5 \%$ doesn't significantly improve the oil extraction from stoned fruits contrary in whole olives.

Extraction from whole olives without addition of talc slightly improves the oil yield compared to stoned fruits (Tab. 2). This limited yield improvement is related to the low moisture content of the paste $(43 \%)$ when crushing the whole olives which impeded the release of the oil. Indeed, 10 to $20 \%$ of the oil remains retained between the solid parts or in the colloidal system of the paste or in emulsion with the water of vegetation (Alba, 2008; Clodoveo, 2012) which requires increase of the pressure time with a slight decrease in pressure to allow the renew of drainage channels within paste followed by an increase of the pressure again to its maximum (LópezVillalta et al., 2008). Nevertheless, following the addition of talc the oil yield is significantly improved to reach more than $20 \%$ in humid and $36 \%$ in dry i.e. an increase of 4.4 and 7.7 percent point respectively compared to the control without coadjuvant (Tab. 2). Espínola Lozano et al. (2009) indicate that the oil yield increases proportionally with the concentration of the talc. A dose of $2 \%$ allows an improvement in yield between 1 and $1.5 \%$ compared to the control. Similarly, Sadkaoui et al. (2017) have shown that the dose of talc influences the yield more than the type of talc used. So, a dose of $2 \%$ allows about $4 \%$ of improvement in oil extraction while an overdose negatively affects the extraction process. Furthermore, Guermazi et al. (2015) obtained their best extraction results by adding $1.5 \%$ of talc while Vidal et al. (2018) recommend not exceeding $0.75 \%$ to achieve an acceptable improvement in extractability. Thus, Caponio et al. (2016) indicate that low 
Table 2. Moisture content in paste $(h)$ and pomace $\left(h^{\prime}\right)$, oil yield in humid $\left(O_{h}\right)$ and in dry $\left(O_{d}\right)$ and degree of acidity of the oils obtained by pressing the paste of whole and stoned olives of the cultivar "Tabelout" in absence or presence of talc as a co-adjuvant during malaxation.

\begin{tabular}{|c|c|c|c|c|}
\hline \multirow[b]{2}{*}{ Parameters } & \multicolumn{2}{|c|}{ Stoned olives } & \multicolumn{2}{|c|}{ Whole olives } \\
\hline & -Talc & + Talc & -Talc & +Talc \\
\hline \multicolumn{5}{|l|}{ Moisture (\%) } \\
\hline Paste $(h)$ & $49.0 \pm 0.3^{\mathrm{a}}$ & $49.1 \pm 0.1^{\mathrm{a}}$ & $42.7 \pm 1.0^{\mathrm{b}}$ & $42.8 \pm 1.1^{\mathrm{b}}$ \\
\hline In humid $\left(O_{h}\right)$ & $15.1 \pm 0.6^{\mathrm{b}}$ & $16.0 \pm 0.7^{b}$ & $16.2 \pm 0.7^{\mathrm{b}}$ & $20.6 \pm 1.0^{\mathrm{a}}$ \\
\hline In dry $\left(O_{d}\right)$ & $29.6 \pm 1.4^{\mathrm{C}}$ & $31.4 \pm 1.5^{\mathrm{B}}$ & $28.3 \pm 1.3^{\mathrm{C}}$ & $36.0 \pm 1.6^{\mathrm{A}}$ \\
\hline Acidity (\%) & $0.65 \pm 0.04^{\mathrm{a}^{\prime}}$ & $0.68 \pm 0.03^{\mathrm{a}^{\prime}}$ & $0.73 \pm 0.03^{b^{\prime}}$ & $0.79 \pm 0.02^{b^{\prime}}$ \\
\hline
\end{tabular}

The different letters indicate a significant difference at a level of $5 \%$.

concentrations of co-adjuvant are preferable particularly when the moisture of the paste is not too high. However, with olives with advanced maturity; Carrapiso et al. (2013) added more than $5 \%$ of talc to improve oil yield by about $1.1 \%$. Therefore, the effect of talc does not depend only on its application dose or the malaxation temperature, but much more on the cultivar and especially on the moisture of crushed olives (Beltrán et al., 2003; Guermazi et al., 2015; Caponio et al., 2016).

The color of olive oil is one of the sensory parameters of appreciation and attraction of the consumer. It depends mainly on the variety, degree of maturity, extraction process and conservation conditions (Tous Martí and Romero Aroca, 1992). In our case, the oil extracted from whole olives without co-adjuvant is less clear compared to that extracted from stoned fruits (Fig. 1). Ranalli et al. (2009) indicate that the stoning allows for cleaner oil than that obtained from whole olives. Likewise, oils extracted in the presence of talc are less turbid and clear than those obtained without the addition of the co-adjuvant (Di Giovacchino et al., 2002b; Carrapiso et al., 2013). Our observations confirm these results (Fig. 1). Indeed, according to Ranalli and Contento (2010), the oil from stoned olives has low pigment concentrations often released by complete crushing of the tissues. Thus, the concentrated color of whole olive oil is probably due to the high content of phenolic compounds released during endocarp crushing (Beltrán et al., 2008) of which the importance seems to be related to genotype and degree of maturity of the fruit (Tous Martí and Romero Aroca, 1992).

The degree of acidity of the different extracted oils was between 0.65 and 0.79 , which indicates that they can be considered as "extra-virgin" oils (acidity $<0.8 \%$ ) (Tab. 2). Indeed, stoning results a decrease in acidity of about $11 \%$ compared to those obtained in oils extracted from whole fruits. Our results are consistent with the observations of Patumi et al. (2003) indicating a decrease in acidity between 6 and 13\% in oils extracted from stoned olives particularly mature. However, Ranalli et al. (2009) and Guermazi et al. (2015) indicate that the stoning at the beginning of ripening reduces the acidity by about $20 \%$. This decrease in acidity is due to inactivation of the enzymes involved in the oxidation of fatty acids. The inactivity is associated with the absence of the stone and kernel rich in lipoxygenases (Ranalli and Contento, 2010) particularly in early-maturing fruit (Patumi et al., 2003). In addition, our results show that the addition of talc to the pressed mass causes a slight increase in the acidity of the oils extracted from stoned or whole olives between 5 and $8 \%$, respectively (Tab. 2). Our results partly match those of Carrapiso et al. (2013) recording a higher acidity by $15 \%$ in the oils obtained from black olives (maturity index between 4 and 5 ) in presence of talc compared to the control. This difference in the decrease of acidity is probably related to the advanced stage of maturity in our case where the fruits have a maturity index of 6.15. However, Fernández Valdivia et al. (2008), Espínola Lozano et al. (2009) and Vidal et al. (2018) did not observe a significant effect of talc on the acidity of the extracted oil. As a result, the influence of talc on oil quality parameters differs from one cultivar to another (Beltrán et al., 2003).

\section{Conclusion}

Our study contributes to the improvement of the traditional extraction system of olive oil by pressure. The addition of talc as co-adjuvant during the malaxation of the paste significantly improves the yield of oil extracted without affecting its quality. Therefore, this significant effect can contribute to enhance the traditional oil mills and avoiding the addition of hot water which affects negatively the quality. In addition, the stoning of olives allows improvement of the paste moisture and obtainment of appreciable oil which can add a value to the local products of the traditional olive-growing by giving them specificity, distinction as well as competitiveness compared to oils produced by modern chains. 


\section{References}

Aït Mouloud M. 2014. La valorisation de la qualité de l'huile d'olive de la région Kabyle: Quel signe de qualité mettre en place? In: Fort F, ed. Terroirs en Méditerranée : concepts, théories, pratiques et perspectives de recherche. Séminaire doctoral «Terroirs en Méditerranée». Montpellier (France) : UMR MOISA. Série de recherches $\mathrm{n}^{\circ} 9$, pp. 67-81.

Alba J. 2008. Elaboración de aceite de oliva virgen. In: Barranco D, Fernández-Escobar R, Rallo L, eds. El cultivo del olivo. Spain: Co-edición Mundi-Press \& Junta de Andalucía, pp. 657-697.

Beltrán G, Uceda M, Jiménez A, Aguilera MP. 2003. Olive oil extractability index as a parameter for olive cultivar characterization. J Sci Food Agric 83: 503-506.

Beltrán G, Uceda M, Hermoso M, Frías L. 2008. Maduración. In: Barranco D, Fernández-Escobar R, Rallo L, eds. El cultivo del olivo. Spain: Co-edición Mundi-Press \& Junta de Andalucía, pp. 163-187.

Boudi M, Chehat F, Cheriet F. 2013. Compétitivité de la filière huile d'olive en Algérie: cas de la wilaya de Béjaïa. Les cahiers du CREAD 105: 89-112.

Bouyoucef D, Laoudj O. 2016. Diversification et valorisation des produits oléicoles: une piste d'avenir pour un développement local, cas du secteur oléicole de la wilaya de Bouira. La Revue des sciences commerciales 15(1): 149-162.

Caponio F, Squeo G, Difonzo G, Pasqualone A, Summo C, Paradiso M. 2016. Has the use of talc an effect on yield and extra virgin olive oil quality? J Sci Food Agric 96: 3292-3299.

Carrapiso AI, García A, Petrón MJ, Martín L. 2013. Effect of talc and water addition on olive oil quality and antioxidants. Eur J Lipid Sci Technol 115: 583-588.

Clodoveo ML, 2012. Malaxation: Influence on virgin olive oil quality. Past, present and future-An overview. Trends Food Sci Tech 25: 13-23.

Di Giovacchino L, Costantini N, Ferrante ML, Serraiocco A. 2002a. Influence of malaxation time of olive paste on oil extraction yields and chemical and organoleptic characteristics of virgin olive oil obtained by a centrifugal decanter at water saving. Grasas $y$ Aceites 53(2): 179-186.

Di Giovacchino L, Sestili S, Di Vincenzo D. 2002b. Influence of olive processing on virgin olive oil quality. Eur J Lipid Sci Technol 104: $587-601$.

EEC. 1991. Commission Regulation (EEC) No.2568/91 of 11 July 1991 on the characteristics of olive oil and olive-residue oil and on the relevant methods of analysis. Official Journal L 248: 00010083. 05/09/1991. Available from https://eur-lex.europa.eu/legalcontent/EN/TXT/PDF/?uri=CELEX:31991R2568\&from=FR.

Espínola Lozano F, Moya Vilar M, Fernández Valdivia DG, Castro E. 2009. Improved extraction of virgin olive oil using calcium carbonate as coadjuvant extractant. J Food Eng 92: 112-118.

FAOSTAT. 2017. Agricol statistics, Olives. Available from http:// www.fao.org/faostat/fr/\#data.

Fernández Valdivia DG, Espínola Lozano F, Moya Vilar M. 2008. Influencia de diferentes coadyuvantes tecnológicos en la calidad y rendimiento del aceite de oliva virgen utilizando la metodología de superficies de respuesta. Grasas y Aceites 59 (1): $39-44$.

García-González DL, Aparicio-Ruiz R, Morales MT. 2014. Chemical characterization of organic and non-organic virgin olive oils. $O C L$ 21(5): 1-6.

Guermazi Z, Gharsallaoui M, Perri E, Gabsi S, Benincasa C. 2015. Characterization of extra virgin olive oil obtained from whole and destoned fruits and optimization of oil extraction with a physical coadjuvant (talc) using surface methodology. J Anal Bioanal Tech 6: 278 .

Hadjou L, Lamani O, Cheriet F. 2013. Labellisation des huiles d'olive algériennes : contraintes et opportunités du processus? New Medit 2: $35-46$.

Hamdi N, Khanouche R. 2007. Création de collections d'olivier et de figuier et leur importance dans le développement rural durable. Recherche agronomique 19: 14-20.

IOC. 2018. World production of olives and olive oil. Available from http://www.internationaloliveoil.org/.

Lamani O. 2014. Huile d'olive de Beni Maouche : critères d'identification et perspectives de valorisation. In: Fort F, ed. Terroirs en Méditerranée: concepts, théories, pratiques et perspectives de recherche. Séminaire doctoral «Terroirs en Méditerranée ». Montpellier (France) : UMR MOISA. Série de recherches $\mathrm{n}^{\circ} 9$, pp. 42-53.

Lamani O, Ilbert H. 2016a. Spécificités de l'oléiculture en montagne (région kabyle en Algérie): pratiques culturales et enjeux de la politique oléicole publique. In: Ater M, Essalouh L, Ilbert H, Moukhli A, Khadari B, eds. L'oléiculture au Maroc de la préhistoire à nos jours : pratiques, diversité, adaptation, usages, commerce et politiques. Montpellier: CIHEAM. Options Méditerranéennes: Série A. Séminaires Méditerranéens no 118, pp. 149-159.

Lamani O, Ilbert H. 2016b. La segmentation du marché oléicole. Quelles politiques de régulation du marché d'huile d'olive en Algérie? New Medit 3: 19-28.

López-Villalta LC, Conteras Carazo RJ, Grana Gil RM. 2008. Obtención del aceite de oliva virgen, Ed. Madrid: Editorial Agrícola Española, 3rd edition, 260 p.

Luaces P, Pérez AG, Sanz C. 2004. Efecto del deshuesado de la aceituna sobre el aroma del aceite de oliva virgen. Grasas y Aceites 55(2): 174-179.

MARDF. 2017. Agricultural statistics of the Ministry of Agriculture and Rural Development and Fisheries, Serie B (Crop production). Algiers, Algeria: Pub. MARDF.

Mendil M. 2009. L'oléiculture: expériences algériennes. In: OLEOMED: 1st Mediterranean Forum of Olive Growing, Algiers, Algeria, 29-30 March 2009.

Patumi M, Terenziani S, Ridolfi M, Fontanazza G. 2003. Effect of fruit stoning on olive oil quality. J Am Oil Chem Soc 80: 249-255.

Preziuso SM, Di Serio MG, Biasone A, Vito R, Mucciarella MR, Di Giovacchino L. 2010. Influence of olive crushing methods on the yields and oil characteristics. Eur J Lipid Sci Technol 112: 1345-1355.

Ranalli A, Contento S. 2010. Analytical assessment of destoned and organic-destoned extra-virgin olive oil. Eur Food Res Technol 230: 965-971.

Ranalli A, Marchegiani D, Pardi D, et al. 2009. Evaluation of functional phytochemicals in destoned virgin olive oil. Food Bioprocess Tech 2: 322-327.

Rugini E, Baldoni L. 2005. Olea europaea Olive. In: Litz RE, ed. Biotechnology of fruit nut crops, biotechnology in agriculture, series No. 29. USA: Ed. CABI International, pp. 403-428.

Sadkaoui A, Jiménez A, Aguilera MP, Pacheco R, Beltrán G. 2017. Virgin olive oil yield as affected by physicochemical talc properties and dosage. Eur J Lipid Sci Technol 119(1): 1600112. https://doi.org/10.1002/ejlt.201600112.

Stefanoudaki E, Koutsaftakis A, Harwood JL. 2011. Influence of malaxation conditions on characteristic qualities of olive oil. Food Chem 127: 1481-1486.

Tous Martí J, Romero Aroca A. 1992. Caracterización del color de los aceites de oliva vírgenes de cultivares catalanes. Grasas y Aceites 43(6): 347-351. 
Uceda M, Frías L. 1975. Épocas de recolección. Evolución del contenido graso del fruto y de la composición y calidad del aceite. In: Proceeding II Seminario Oleicola Internacional, IOC, Córdoba, Spain, 1975, pp.125-128.

Uceda M, Hermoso M, Aguilera MP. 2008. La calidad del aceite de oliva. In: Barranco D, Fernández-Escobar R, Rallo L, eds. El cultivo del olivo. Spain: Co-edición Mundi-Press \& Junta de Andalucía, pp. 699-727.

Vidal AM, Alcalá S, De Torres A, Moya M, Espínola F. 2018. Use of talc in oil mills: Influence on the quality and content of minor compounds in olive oils. LWT-Food Sci Technol 98: $31-38$.

Cite this article as: Titouh K, Mazari A, Aït Meziane MZ. 2020. Contribution to improvement of the traditional extraction of olive oil by pressure from whole and stoned olives by addition of a co-adjuvant (talc). OCL 27: 23. 